\title{
Flipping the Classroom at Scale to Achieve Integration of Theory and Prac- tice in a First Year Engineering Design and Build Course
}

\author{
Dr. Carl A Reidsema PhD, The University of Queensland
}

Associate Professor Carl Reidsema, University of Queensland Associate Professor Reidsema is a mechanical design engineer with over 12 years industry experience. Beginning his academic career at the University of New South Wales in 2001, he led the Faculty development of the first hands-on activelearning team based first year common course in engineering design "ENGG1000 - Engineering Design and Innovation" involving over 1100 students. In 2010 he was appointed to the position of Director of Teaching and Learning for the Faculty of Engineering at the University of Queensland in where he then led the successful development of the Flipped Classroom model for integrating theory with design practice in a first year engineering design course "ENGG1200 - Engineering Modelling and Problem Solving" with over 1200 students. Dr. Reidsema's work is centred around the notion of Transformational Change in Higher Education which is reflected by his success in securing grants and industry funding for research and development in this area exceeding \$3M including a 2008 Australian Learning and Teaching Council (ALTC) Project "Design based curriculum reform" and the 2013 Office of Learning and Teaching (OLT) Project "Radical transformation: re-imagining engineering education through flipping the classroom in a global learning partnership" partnering with Stanford, Purdue, Pittsburgh, Sydney RMIT universities. He has received numerous nominations and awards for teaching including the UNSW Vice Chancellor's Teaching Excellence Award in 2006 and has over 60 peer-reviewed publications in engineering education and design. He is regularly invited to speak on the topic of transformational change and innovative curriculum at Universities and Industry events.

\section{Dr. Lydia Kavanagh, The University of Queensland}

Since returning to academia from industry in 1998, Associate Professor Lydia Kavanagh has become a leader in engineering education and has used her background as a professional engineer to design both curricula and courses for active learning by combining real-world projects and specialist knowledge. She has had a significant impact on the delivery of UQ's undergraduate engineering program through creative new teaching pedagogies including the Flipped Classroom, innovative authentic approaches to assessment, and the introduction of multi-disciplinary courses. As Director of First Year Engineering, Lydia is also responsible for a significant program of extra-curricular transition support for first year students. Lydia's work was recognised with a national Excellence in teaching award in 2011 and she has lead and participated in national projects on teamwork, online learning, curriculum innovation ( $2 \mathrm{x})$, preparing students for first year engineering, and Flipped Classrooms.

\section{Dr. Lesley Jolly, Strategic Partnerships}

My original work as an anthropologist was with Australian indigenous peoples but in 1996 I was approached to undertake an ethnography of the first-year engineering class at the University of Queensland with a view to understanding the gender dynamics there. Since then my association with engineers and engineering has grown to dominate my research life. I have continued to pursue my contact with engineers through a variety of research projects, the supervision of $\mathrm{PhD}$ students in engineering problems that have social dimensions and by establishing and leading the new Research Methods Interest Group of the Australasian Association for Engineering Education (AAEE). In that capacity I have run workshops on research methods and educational evaluation in Australia and New Zealand and was a founder leader of the annual AAEE Winter School for engineering education research. In the last three years I have completed two CRC projects; Evaluation of Simulators in Train Driver Training and Towards a National Framework for Competence Assurance for Train drivers. I have also recently managed an ALTC project called Curriculum Change through Theory-Driven Evaluation on behalf of the University of Queensland. 


\title{
Flipping the Classroom at Scale to Achieve Integration of Theory and Practice in a First Year Engineering Design and Build Course
}

\begin{abstract}
There are a number of challenges in the development of first year inter-faculty engineering "cornerstone" design courses, not least of which is the need to integrate engineering fundamentals (theory) with engaging authentic team-based design (practice). Achieving this integration requires deliberate alignment of fundamentals to what can be wide variations in both academic and student conceptions of discipline. Within a course, integration must be achieved such that concepts are constructively aligned to the downstream artefacts of multiple hands-on design projects to avoid being interpreted as additional material to be learned but irrelevant to major assessment goals. A further challenge in an environment of ever-increasing class sizes is the development of an approach that allows for scale-up, yet also ensures students actually achieve requisite theoretical knowledge, professional ability, and behavioural learning outcomes.
\end{abstract}

A large scale (1200 students) Flipped Classroom (FC) second-semester first-year engineering compulsory course was designed, implemented, operated and evaluated at a leading researchintensive university in Australia over the past 3 years to address these challenges. The FC model, where material is delivered online allowing face-to-face interactions to be grounded in authentic disciplinary practices, aligned with the need for scale-up. Integrating theory with practice in this way is necessary to drive deeper conceptual understanding of engineering fundamentals 2,9 . This paper will elaborate on the curriculum design rationale for this course, its implementation, and the results of the extensive and ongoing evaluation. The methods and process detailed in the paper can be used to aid similar processes.

\section{Introduction}

Despite decades of debate and effort towards achieving an acceptable balance of theory and practice within engineering curricula, educational programs still predominantly reflect the centuries old traditional engineering science model. In this model the fundamental concepts of mathematics and science are viewed as content that is prerequisite to practice and delivered to students as abstracted cognitive instruction through a sequence of lectures, tutorials and examinations. Despite a strong demand by engineering stakeholders for increased emphasis on engineering ability and professional competencies, there is little opportunity within this model for these to be addressed within the types of authentic contexts that are required if learning is to be situated as practice ${ }^{3}$. While Capstone project-based design courses have found their place as culturally acceptable vehicles for many of the engineering ability and professional competencies required for accreditation ${ }^{7}$, their location within the curriculum prevents the scaffolded development of these competencies. If engineering theory-practice was initiated in first year, and carried through subsequent years, the Capstone course could demonstrate not only application of content learnt but also more fully developed professional competencies. However first year design courses are generally perceived as not capable of delivering theory, first year students as not having the knowledge required to complete authentic projects and consequently, these courses are often labelled as being insufficiently rigorous.

If we are to pursue the development of engineering competencies from the first year, then we must practice what we preach and find a way to get our students actively involved and 
engaged in their learning. They must not only do meaningful learning activities but also think (and consequently communicate their understanding) about what they are doing. This "Active learning" can be "contrasted to the traditional lecture where students passively receive information from the instructor."11 (p.1). While there has been some resistance to the idea that this style of learning is more effective, as Prince himself notes, it resonates with a school of thought in education known as situated cognition ${ }^{11}$ which holds that "meaningful learning takes place in complex authentic situations, not in isolation. The interaction of learners with these situations influences their ability to develop a meaningful understanding of new concepts and skills and to transfer skills to other relevant situations. Providing students with opportunities to allow the context of a situation to guide their learning more closely simulates how people learn in real-world situations"12. Seely Brown et. al. compared how JPFs (Just Plain Folks), Students and Practitioners learn to demonstrate the artificiality of most learning situations (Figure 1). Our graduate engineers need to be Practitioners and therefore we must to take our cues from Figure 1 and provide our students with ill-defined problems and the opportunity to construct meaning with their mentors and peers. It should be noted that there is no contradiction between this position and the non-negotiability of many of the facts that engineers work with. It is just that before students can begin to work like engineers, they need to develop an appreciation of the significance and use of those facts as the discipline sees them.

\begin{tabular}{llll} 
& JPFs & Students & Practitioners \\
\hline reasoning with: & causal stories & laws & causal models \\
acting on: & situations & symbols & conceptual situations \\
resolving: & emergent problems & well-defined & ill-defined \\
& and dilemmas & problems & problems \\
producing: & negotiable meaning & fixed meaning & negotiable \\
& \& socially & \& immutable & meaning \\
& constructed & concepts & \& socially \\
& understanding & & constructed \\
& & & \\
& & & \\
\hline
\end{tabular}

Figure 1: JPF, Practitioner and Student Activity ${ }^{11(\text { p. 35) }}$

The Flipped Classroom (FC) provides a potential solution to these challenges ${ }^{1,8}$ : meaningful active learning, embedded and scaffolded authentic practice across the curriculum, the opportunity to socially construct understanding, and therefore the introduction of rigour to first year design courses. For the purposes of this paper, the FC is defined as a model of teaching where content is delivered online for students to access in their own time and space, thus allowing face-to-face interactions to be active sessions grounded in authentic disciplinary practices. Most importantly, the FC model is student-centred; each student is responsible for coming to class with a basic understanding of the content, so that they can fully participate and engage in class discussion ${ }^{8}$. Integrating theory with practice in this way is necessary to drive deeper conceptual understanding of engineering fundamentals ${ }^{2,9}$.

The increasing capabilities of online learning tools, and the ease with which short, high quality "content-oriented" learning videos can be created (a priori or as needed), delivered and re-used, also allow for ongoing adaptive curriculum design refinement to occur. The big question is whether this is possible at scale and as an integrated part of a curriculum. 
This paper reports on a large scale (1200 students) FC first-year engineering course that was designed, implemented, operated and evaluated at a leading research-intensive university in Australia over the past 3 years to address these challenges. A model of development, including integration into existing curriculum, is presented using CDIO (Conceive, Design, Implement and Operate) as a descriptive framework.

\section{Conceive}

It is not often that engineering educators get blank canvas opportunities to innovate as was the case at The University of Queensland (Australia) in mid-2010. The Faculty of Engineering had just completed a year-long major review of its curriculum to examine the effectiveness of its existing programs as a basis for creating a new 5-year combined Bachelor Engineering/ Master Engineering (BE/ME) program. The end product was envisaged as an alternative to the Bologna style curriculum offered by other institutions. The BE/ME would instead build on the existing 4-year BE degree and focus on achieving a distinctive engineering theory-practice flavour. The curriculum review recommended that the existing first-semester common first-year Cornerstone course (ENGG1100 Engineering Design) be complemented with a second-semester common course that developed design theory-practice skills (ENGG1200 Problem Solving and Modelling).

To add to the challenge, over the previous 7 years, student enrolments had expanded by nearly 200\% with numbers reaching over 1200 in 2013 and thus the need to achieve and maintain high entry qualifications standards, high levels of student engagement and satisfaction and minimum attrition needed to be recognised. Reflecting this overall vision, the final report of the review recommended:

In developing the new curriculum, more extensive use should be made of pedagogies based on engineering design, build and test that are engaging and relevant, incorporate authentic, active learning in realistic situations, are technically rigorous and incorporate professional behaviour outcomes.

The decision to operate the new course as a FC was made partly in response to the need to engage a large cohort and partly as a response to the need to integrate theory and practice.

Design is an iterative process whose eventual solution quality hinges critically and completely on the degree to which the problem being addressed is as well understood as time and resources permit. To that end, an entire year was devoted to the design problem definition phase of the new course before moving to the Design Stage. To begin, a course mapping template, developed in a previous study ${ }^{6}$, was used as a tool to ensure that the context in which the course was to be offered was fully understood by all stakeholders. Spaces and tools are notably absent from this map but it was agreed that the former would be found and the latter developed as necessary. 


\begin{tabular}{|c|c|c|c|}
\hline $\begin{array}{l}\text { Institutional Context } \\
\text { - Public funded/research intensive } \\
\text { - Ranked } 2^{\text {nd }} \text { (Australia) and in the } \\
\text { top } 100 \text { internationally } \\
\text { - } 100 \text { years old } \\
\text { - Recent edX member } \\
\text { - } 1200 \text { students enrolled annually in } \\
\text { engineering } \\
\text { - Teaching Focused (TF) academic } \\
\text { program } \\
\text { - Strong but informal SOTL strength } \\
\text { in engineering and science }\end{array}$ & $\begin{array}{l}\text { Course Design/ Delivery } \\
\text { - Engineering Modelling and } \\
\text { Problem Solving through authentic } \\
\text { team based major design/build } \\
\text { projects } \\
\text { - Flipped Class mode with } \\
\text { engineering materials concepts } \\
\text { delivered through online videos } \\
\text { - Entirely active learning/no lectures } \\
\text { - Balanced individual/team learning }\end{array}$ & $\begin{array}{l}\text { Instructor Characteristics } \\
\text { - Professorial leadership with } \\
\text { extensive industry experience } \\
\text { - Award winning TF academics } \\
\text { - Learner/student focused } \\
\text { - Change agents } \\
\text { - Project leaders and tutors carefully } \\
\text { selected - enthusiasm, desire to } \\
\text { work with first years, ability to } \\
\text { challenge students } \\
\text { - Teaching team } \sim 40\end{array}$ & $\begin{array}{l}\text { Student Characteristics } \\
\text { - } 100 \% \text { transfer from ENGG1100 } \\
\text { with similar demographics } \\
\text { - Multiple engineering disciplines } \\
\text { - Mix of engineering statics, thermo, } \\
\text { electrical fundamentals } \\
\text { - Mix of } 1^{\text {st }} \text { year maths ability } \\
\text { - Improved social networks } \\
\text { - Improved conceptions of degree } \\
\text { major }\end{array}$ \\
\hline $\begin{array}{l}\text { Community Expectations } \\
\text { - Engineers Australia (EA) } \\
\text { - Emphasis on theory-practice, } \\
\text { critical thinking, engineering ability } \\
\text { - Grow Industry funding through } \\
\text { student project sponsorship } \\
\text { (Boeing, ABB, Barnes Foundation } \\
\text { etc.); }\end{array}$ & $\begin{array}{l}\text { Learning Objectives } \\
\text { - Appreciation of mathematical/ } \\
\text { virtual/physical modelling } \\
\text { - Application of engineering } \\
\text { materials behaviour in design } \\
\text { - Demonstrated ownership of } \\
\text { learning } \\
\text { - Reflective writing for design } \\
\text { thinking and planning } \\
\text { - Effective team skills } \\
\text { - Use of design process }\end{array}$ & $\begin{array}{l}\text { Instructor Motivation } \\
\text { - Largely intrinsic rewards for degree } \\
\text { of effort } \\
\text { - High probability of promotion } \\
\text { through change leadership } \\
\text { - Opportunity to engage in research } \\
\text { around design learning and } \\
\text { transformational change } \\
\text { - High degree of ownership but } \\
\text { significant teaching team } \\
\text { autonomy }\end{array}$ & $\begin{array}{l}\text { Student Motivation } \\
\text { - Still predominantly strategic } \\
\text { learners } \\
\text { - Strong desire for authentic } \\
\text { learning and experiences } \\
\text { - Seeking relevance } \\
\text { - Developing levels of ownership } \\
\text { and identity } \\
\text { - Critical team players }\end{array}$ \\
\hline $\begin{array}{l}\text { Curriculum Context } \\
\text { - Course Evaluation results } \\
\text { - EA commendation } \\
\text { - Academic conceptions of technical } \\
\text { rigour } \\
\text { - Industry recognition } \\
\text { - National awards received } \\
\text { - Balance research intensive image } \\
\text { with real world authentic learning }\end{array}$ & $\begin{array}{l}\text { Assessment } \\
\text { - Varied assessment types } \\
\text { - Online MCQ/written reflections } \\
\text { - Team design reports } \\
\text { - Structured activity templates } \\
\text { - } \text { product performance } \\
\text { - Team peer review }\end{array}$ & $\begin{array}{l}\text { Teacher Behaviours } \\
\text { - Emphasis on teaching as } \\
\text { facilitation and coaching } \\
\text { - Emphasis on experiential learning } \\
\text { - Extensive use of PG/UG tutors } \\
\text { - Extensive use of Facebook/email/ } \\
\text { LMS communication modes } \\
\text { - Strong emphasis on developing } \\
\text { student's agency }\end{array}$ & $\begin{array}{l}\text { Student Behaviours } \\
\text { - Predominantly strongly motivated } \\
\text { - Mixed cohort of epistemological } \\
\text { developmental levels ( } 3-4 \text { Perry) } \\
\text { - Accepting of challenges } \\
\text { - Struggle with teaching vs learning } \\
\text { - High degree of participation }\end{array}$ \\
\hline
\end{tabular}

Figure 2 Course Context Map

Engaging stakeholders in the process of conceptual course design was necessary for a number of reasons: to ensure the course achieved the design objectives, to ensure that there was buyin across the four year engineering degree program, to fully understanding the potentials and constraints of the environment, to explore and establish collaborations and to ensure that expertise was engaged where necessary. Stakeholders included: The University of Queensland's technology and innovation unit (CEIT), an educational designer, the firstsemester course coordinator, various academics from the Faculty of Engineering from the Executive Dean to engineering materials research experts, and machine shop staff. In addition, peers from other institutions were given various conceptual drafts for their comment.

With the context of the course mapped, and stakeholders engaged, the next step was to set realistic learning goals based on a "rationale that reflects the beliefs, theories and assumptions about engineering practice, educational goals and learning, ${ }^{, 5}$ (148) . The new course needed to shift in its treatment of design from the preceding first-semester course towards the application of virtual prototyping and physical manufacturing of behaviourally accurate subsystem assemblies. A key learning outcome was to make explicit the extent to which virtual models can be relied upon to accurately predict the performance of physical models. In addition, the course learning goals were to include engineering materials science and problem solving and modelling. Concept maps around these goals were developed with relevant experts and the online FC content was based on these maps. Lectures were to be replaced with large (600 students) active learning workshops facilitating the development of design process knowledge through collaborative learning. Technical learning outcomes (engineering materials and modelling/ problem solving) were to be addressed through smaller active and 
cooperative learning workshops (90 students), aligned to an in-house custom designed videobased online learning system.

\section{Design}

The elements of ENGG1200 are summarised in Table 1.

Table 1 An overview of ENGG1200

\begin{tabular}{|c|c|}
\hline Element & \\
\hline $\begin{array}{l}\text { Learning } \\
\text { Objectives }\end{array}$ & $\begin{array}{l}\text { 1. Materials I: describe atomic/ micro-structural characteristics of materials; explain } \\
\text { elastic modulus/ composite moduli; describe mechanisms for plastic flow in metals/ } \\
\text { strength enhanced micro-structure. } \\
\text { 2. Materials II: describe/ analyse stress-strain response, determine effect of } \\
\text { temperature and time under load, choose materials based on properties. } \\
\text { 3. Problem Solving: solve engineering problems using framework; sketch, define } \\
\text { scope; propose model, incl. variables/ constants/ assumptions/ sensitivities. } \\
\text { 4. Modelling: Produce model/ simulation flow chart; use Matlab to solve developed } \\
\text { model; verify model; validate simulation results; use Creo to design and develop } \\
\text { structural model; create CNC tool path; produce 2D working drawings. } \\
\text { 5. Design: Use design thinking/ reflexive practice to plan/ implement/ design } \\
\text { engineering solution. } \\
\text { 6. Manufacturing: Use knowledge of manufacturing/ materials to build prototype. } \\
\text { 7. Communication: build on ENGG1100 lessons; develop writing coherence/ } \\
\text { rationale; master graphics, data, and word processing software. } \\
\text { 8. Team Work: devise/ implement strategies based on critical personal reflections to } \\
\text { improve team performance and fast track team development. }\end{array}$ \\
\hline Assessment & $\begin{array}{l}\text { 1. Online material quizzes }(6 \mathrm{x})-10 \% \text {, individual submission, hurdle assessment (i.e. } \\
\text { must be passed) } \\
\text { 2. Problem solving book }(6 \mathrm{x})-5 \% \text {, team submission } \\
\text { 3. Reflections }(5 \mathrm{x})-15 \% \text {, individual submission } \\
\text { 4. Preliminary memo - } 15 \% \text {, team submission } \\
\text { 5. Mid-semester concept exam - } 20 \% \text {, individual submission, hurdle assessment (i.e. } \\
\text { must be passed) } \\
\text { 6. Prototype demo - } 20 \% \text {, team submission } \\
\text { 7. Final report }-5 \% \text {, team submission }\end{array}$ \\
\hline $\begin{array}{l}\text { Learning } \\
\text { Activities }\end{array}$ & $\begin{array}{l}\text { Workshops; online modules; Virtual model test; demo day; See Implementation section } \\
\text { below for details }\end{array}$ \\
\hline $\begin{array}{l}\text { Curriculum } \\
\text { Objectives }\end{array}$ & $\begin{array}{l}\text { Theory-Practice (as per Figure 1) } \\
\text { Ownership of Learning (as per FC pedagogy) }\end{array}$ \\
\hline
\end{tabular}

The course was designed to be "front-ended", that is content was offered early in semester with the last weeks of semester devoted to student teamwork with no formal contact sessions, as shown in Figure 3. Along the bottom of the diagram, the stages of the design project are shown; along the top are the written reflections that formed part of the assessment (Assessment 3., Table 1) and that were implemented to encourage ownership of learning through meta-level review. These reflections were based around a number of trigger questions that asked students to cognitively recognise and communicate how they were learning, what they were learning, and their level of competence in the context of engineering design and themselves as an engineer. 


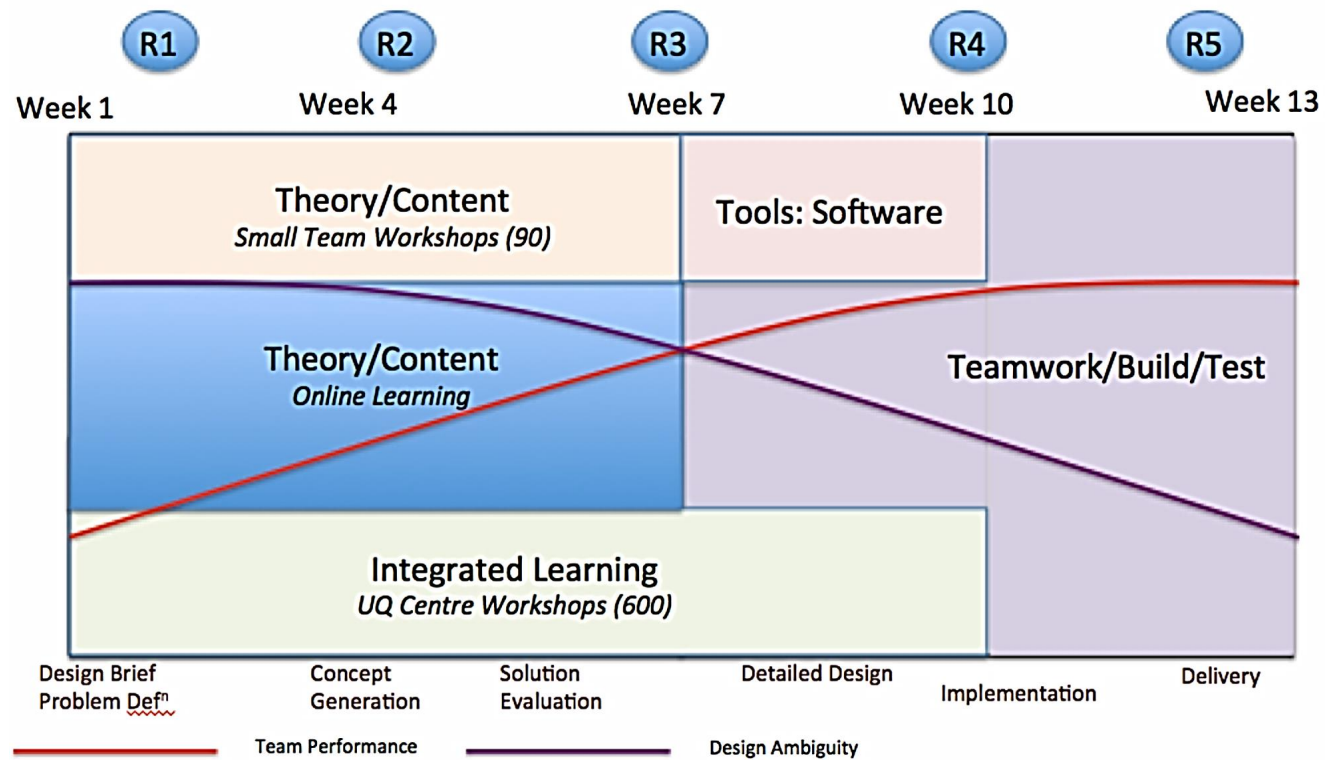

Figure 3 ENGG1200 schedule

Both "Theory/ Content" sessions shown in Figure 3 followed a FC approach, as did the "Integrated Learning" workshops with content placed online and active facilitated sessions replacing lectures. The former sessions covered Learning Objectives 1 to 4 (Table 1) and the latter workshop was used to allow students to negotiate meaning and construct understanding in a social context through guided collaborative exercises. The "Tools: Software" sessions were computer laboratories where students learnt Matlab and Creo: the tools necessary to virtually and physically construct their prototype.

\section{Implementation}

Table 2 details the implementation of ENGG1200 for a cohort of approximately 1200 students; it should be read in conjunction with Figure 3.

Table 2 ENGG1200 implementation details

\begin{tabular}{|l|l|c|l|l|l|}
\hline $\begin{array}{l}\text { Figure 3 } \\
\text { notation }\end{array}$ & Session type & $\begin{array}{l}\text { Objectives } \\
\text { (Table 1) }\end{array}$ & Resources & Space & Assessment \\
\hline $\begin{array}{l}\text { Theory/ Content } \\
\text { (Small team } \\
\text { workshops, 90) }\end{array}$ & $\begin{array}{l}\text { Team-based: } \\
\text { laboratory (1 h/w) } \\
\text { problem-based } \\
\text { workshop (1h/w) }\end{array}$ & $1,2,8$ & $\begin{array}{l}\text { Worksheets; } \\
\text { Tutors; Lab } \\
\text { equipment }\end{array}$ & $\begin{array}{l}\text { Flat floor; round } \\
\text { tables; 6 } \\
\text { students/ table; } \\
\text { computers }\end{array}$ & $\begin{array}{l}\text { End of session } \\
\text { tutor marking }\end{array}$ \\
\hline $\begin{array}{l}\text { Theory/ Content } \\
\text { (Online learning) }\end{array}$ & Online & 1,2 & $\begin{array}{l}\text { Podcasts, } \\
\text { Readings, } \\
\text { Quiz Tool }\end{array}$ & NA & $\begin{array}{l}\text { Weekly } \\
\text { quizzes; } \\
\text { Midterm exam }\end{array}$ \\
\hline $\begin{array}{l}\text { Integrated } \\
\text { learning (XX } \\
\text { Centre, 600) }\end{array}$ & $\begin{array}{l}\text { Collaborative } \\
\text { active learning }\end{array}$ & $3,4,5,7,8$ & $\begin{array}{l}\text { Paper } \\
\text { worksheets; } \\
\text { Facilitators }\end{array}$ & $\begin{array}{l}\text { Flat floor; round } \\
\text { tables; 9 } \\
\text { students/ table }\end{array}$ & $\begin{array}{l}\text { Worksheets } \\
\text { submitted with } \\
\text { major reports }\end{array}$ \\
\hline Tools: Software & $\begin{array}{l}\text { Team-based } \\
\text { computer lab } \\
\text { sessions }\end{array}$ & $3,4,5$ & $\begin{array}{l}\text { Tutors; CAD/ } \\
\text { MatLab; } \\
\text { worksheets }\end{array}$ & $\begin{array}{l}\text { Computer } \\
\text { laboratories }\end{array}$ & $\begin{array}{l}\text { Virtual Model } \\
\text { Feasibility } \\
\text { Package }\end{array}$ \\
\hline $\begin{array}{l}\text { Teamwork/ } \\
\text { Build/ Test }\end{array}$ & $\begin{array}{l}\text { Student booked } \\
\text { machine shop/ } \\
\text { electrical lab }\end{array}$ & $6,7,8$ & $\begin{array}{l}\text { Handtools; } \\
\text { CNC; Test } \\
\text { Rigs }\end{array}$ & $\begin{array}{l}\text { Laboratories; } \\
\text { undercover } \\
\text { outdoor areas }\end{array}$ & $\begin{array}{l}\text { Project Criteria } \\
\text { Sheets; Demo- } \\
\text { nstration }\end{array}$ \\
\hline
\end{tabular}




\section{Operation}

In its first year of operation, 2012, the course underwent student evaluation using the standard institutional survey instrument (Table 3). In 2013, a more broad-based external evaluation was undertaken drawing on observational, survey and interview data, but including the standard instrument to explore issues further. Figure 4 compares the standard instrument results for 2012 and 2013.

Table 3: general student response survey questions

\begin{tabular}{|c|l|}
\hline Item & Detail \\
\hline 1 & I had a clear understanding of the aims and goals of the course. \\
\hline 2 & The course was intellectually stimulating. \\
\hline 3 & The course was well structured. \\
\hline 4 & The learning materials assisted me in this course. \\
\hline 5 & Assessment requirements were made clear to me. \\
\hline 6 & I received helpful feedback on how I was going in the course. \\
\hline 7 & I learned a lot in this course. \\
\hline 8 & Overall, how would you rate this course? \\
\hline
\end{tabular}

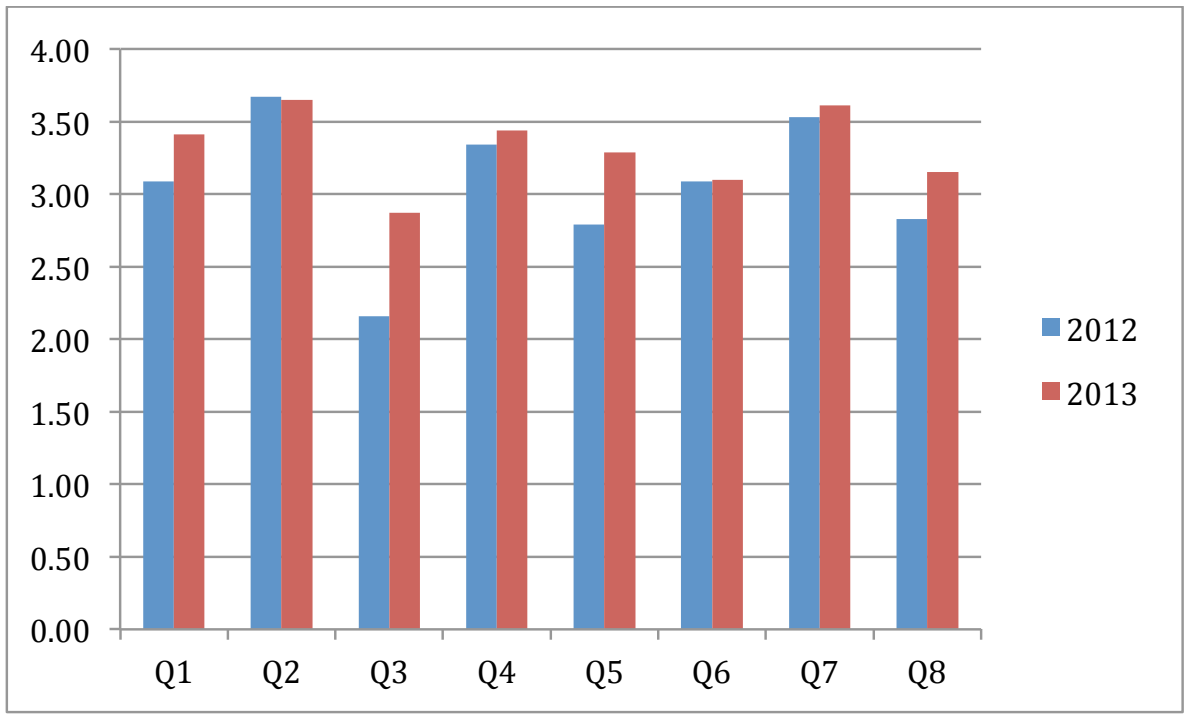

Figure 4: Comparison 2012/13 student evaluation results (Scale 1-5, 5=Strongly agree)

A significant issue arising out of the 2012 evaluation results was the mismatch between student expectations and the aims and structure of the course (Q3, Figure 4). Question 3 asked students whether they perceived the course to be well-structured or not and in 2012, they perceived that it wasn't. Entwhistle and Peterson ${ }^{4}$ have said that first year student conceptions of learning align with "being taught" and having what they need to know clearly stated with resources that are familiar to them laid out and well-structured. In addition, students" expectation of a "well-structured" learning experience are created by prior learning experiences, can be expected to be at odds with the inherent "ill-structuredness" of engineering design, and will be affected by an unfamiliar course structure such as the FC. 
The response to the 2012 ratings was to create more and better opportunities to communicate the expectations and rationale of the unfamiliar structure. The primary change was to run the "Integrated Learning" workshops (Figure 3), developed with the express purpose of communicating the course narrative to the students and helping them structure their learning. In addition, communication and support tools such as an online Q\&A tool, Facebook forum and online tutoring were provided. These online resources were organised through an inhouse developed "Learning Pathway" tool that provided links to what students needed to know and what they needed to do. The Learning Pathway tool organised and presented this information on a weekly basis. The results of these improvements are apparent in Figure 4 but more is needed to communicate the rationale in ways that make sense to students (see discussion below).

Observation of student learning activities revealed many unexpected insights into what students need to learn and how they go about learning it, from the group in the workshop who could not recognise drill bits to the group who were reluctant to accept the tutor's advice to "just build the circuit" because their simulation suggested there would be a fault with it. This data is still to be analysed in full and will be discussed in a future paper ${ }^{10}$ but already it can be seen that standard assessment and evaluation criteria are perhaps not best suited to capturing such fugitive but key learning moments, a point that arises also from examination of the student response data.

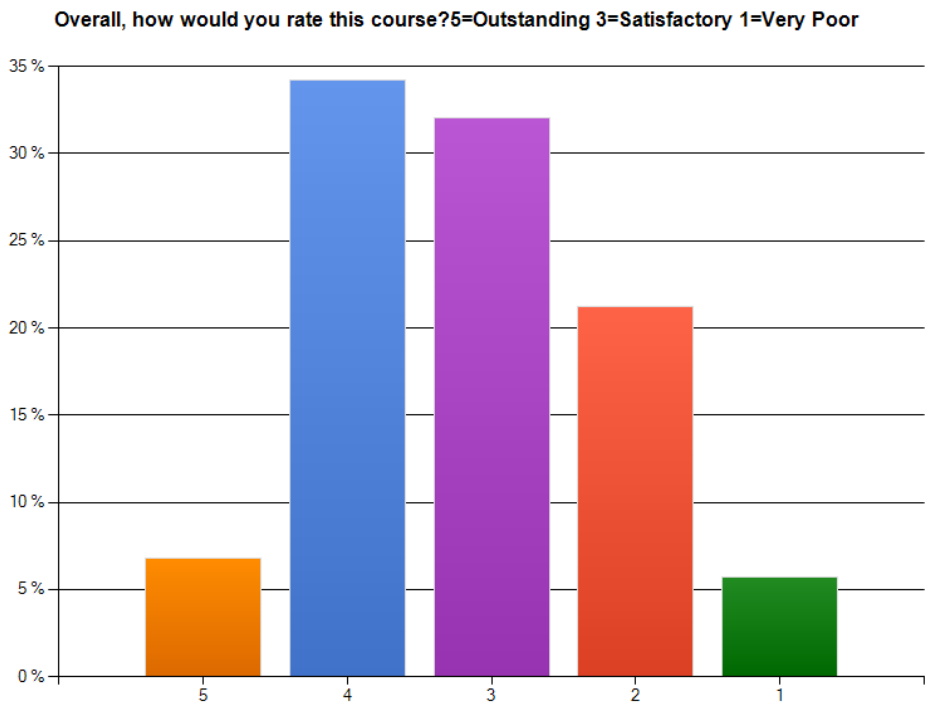

Figure 5: Students' rating of the course overall

In 2013, 368 students completed an end of course online survey: about $30 \%$ of the total enrolment. This was part of a multi-method evaluation but here we will concentrate on the survey results. As shown in Figure 5, despite the unfamiliarity of the FC format and the (intentionally designed) heavy workload demands, $73 \%$ of the respondents rated the course as satisfactory or better. Although teamwork-based courses often are deeply unpopular with students, in this course "working with other people" was rated as the easiest part of the course. Delving deeper into this data (Figure 6), students reported that they supported each other, that talking with other students developed understanding and that they could work comfortably with other students. Being able to work with other people was rated as the 
greatest gain from the course, followed by "being responsible for my own learning" and knowledge and understanding of topics covered. When asked how much they had gained from the course, $72 \%$ responded with the two highest categories of "a lot" or "quite a lot".

How much do you feel you have gained from studying this course?

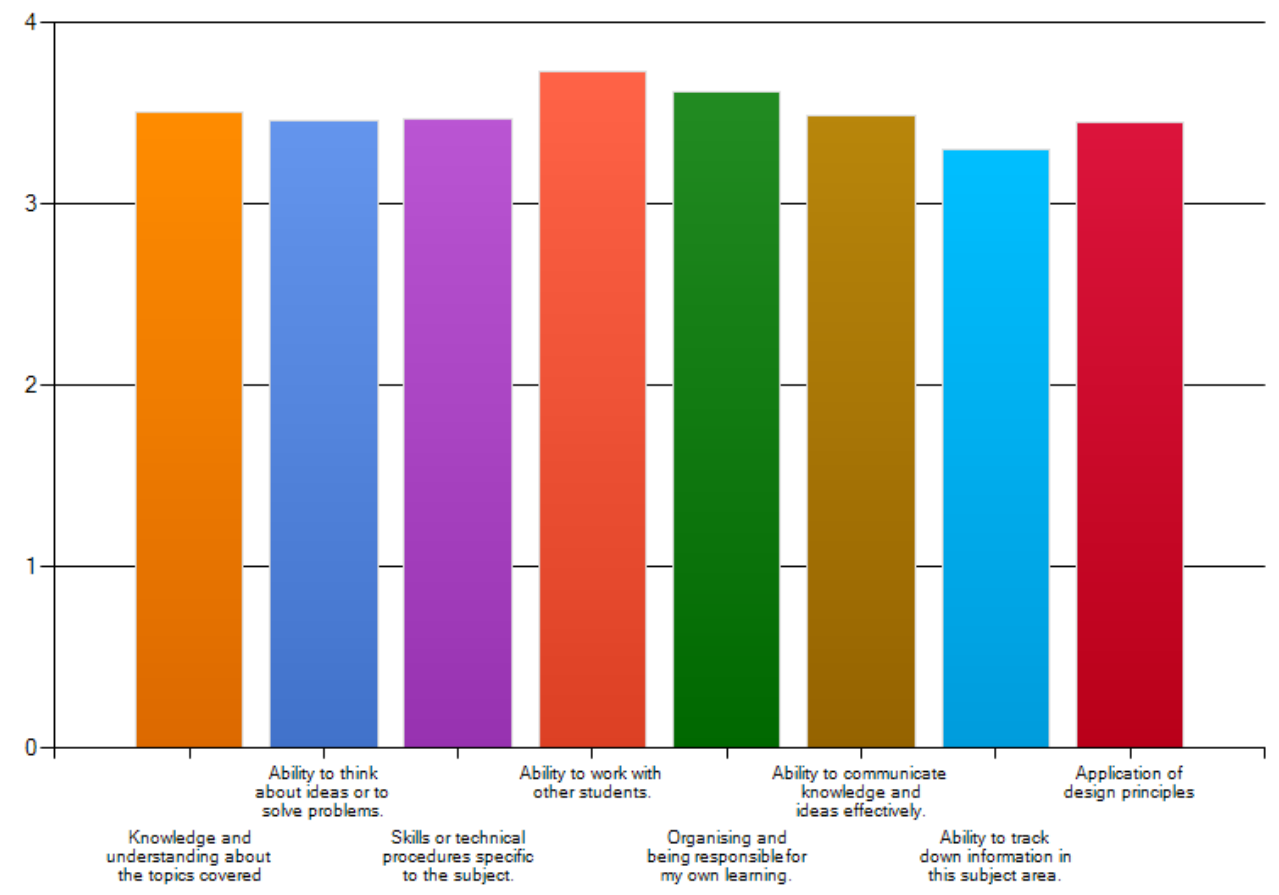

Figure 6: Students' ratings of gains from the course.

The majority of the students identified the practical aspects of the course including the building of a prototype, the theory-practical links and the freedom to arrive at one's own solution in response to the open-ended question asking what was best about the course:

ENGG1200 is also very unique from other classes, giving us a taste of the big picture and how it's done in the real world, rather than just the knowledge-based learning (mathematics, physics) for the practical application of skills. For these reasons I feel that this is a very valuable course. (Student survey response, 2013)

The staff presence and guidance, including on Facebook, was the next most mentioned category, followed by the increased learning resulting from working in a team with different approaches and perspectives. Although there was a great deal of acknowledgement of the benefits of teamwork, its difficulties were also acknowledged:

The "own your learning" concepts I've found to be invaluable even at the early stage of university, and working with other students in a group. The team effort is difficult and annoying at times, but I don't undermine the value of such an experience and the necessity of it. (Student survey response, 2013)

Like that student, many others took the opportunity to reflect on the effect the course had on their work and study habits, that is, their professional practice. 
It really makes you push yourself to be organised and keep on top of everything that needs to be done. This really does wonders to advancing your own personal responsibility, especially when you couple this personal responsibility with the responsibility you have to your team. (Student survey response, 2013)

Another open-ended question asked students to make suggestions about what needed to be improved in the course. While this is an invitation to the disaffected to grumble, the overall patterns of response are helpful. For instance, there were many complaints about the need for more communication about the objectives and rationale for the course.

I understand the importance of doing self-learning and I know that I am responsible enough to do this so I do not feel that it was my own self-discipline that was the problem. I believe that the course could have been structured better to help students to learn materials. Firstly, the information itself needs to be improved - someone needs to be able to clearly highlight what we need to learn, tie it all together in a structured way, and go through the information to remove repetition. (Student survey response, 2013).

This student has clearly given the matter some thought and their appeal for clearer information about what they need to learn was echoed many times in the data. Rather than see this as a variation on "will this be on the test?", the response is thought to indicate that the FC is indeed a revolutionary experience for most students and that students need to know that the kinds of learning we are interested in go beyond mastering gobbets of data, and the required behaviour is rewarded. This may require a rethink of assessment as there is no clearer way to communicate intentions to students than through assessment criteria. As another student said:

I like the way I had to manage my learning and find things for myself. A lot of people don't seem to like learning in this way or they are not used to it. Just develop course a bit more it is made clear what procedures are meant to be understood for assessment. (Student survey response, 2013)

As far as the use of online learning modules went, there was surprisingly little comment from students, and what there was tended to be along the lines of:

Instead of learning all the materials content online I think could have learnt it in lectures or in-class tutorials and it might not have taken up so much time, and it would've been easier to learn. I don't learn very well by just reading so it was very hard to take all that information on-board. (Student survey response 2013)

While some of this response can be accounted for by a student's preference for, and past experience of passive content delivery, it also suggests that they failed to realise the importance of not just reading to absorb information, but working through it with the team to make sense of how to apply the information to the problem at hand. Once again, more and better communication about the expected learning process seems to be the need.

\section{Discussion}

As previously noted, there is strong theoretical support for authentic and active learning and a need to address Seely Brown et. al.'s ${ }^{11}$ contrast between how JPFs, traditional students and 
practitioners learn. As they noted, "normal" classroom practice replaces the conditions experienced in real world problem solving, as experienced by JPFs and practitioners, with simplified but abstract laws and well-defined problems. The development of professional practice cannot be built on such methods. Instead students need to start to learn as professionals do, starting by reasoning with causal models.

They also need to engage with conceptual situations rather than symbols. In the large group sessions, workshops and during the prototyping process, students were manipulating concepts that will recur in their practice including how to resolve design issues or negotiate a difference of opinion in their team. Abstract mathematical manipulation and calculation is an important part of engineering design, but it becomes meaningful and effective only when the practitioner can apply it. By requiring students to understand underlying conceptual situations with the aim of active application (acting), authentic learning was delivered and students rated the hands-on nature of this course highly.

It is rare that practitioners deal with well-defined problems with limited solutions and therefore to present such problems to students will limit their ability to deal with the many different ways in which real world problems present themselves. The new course therefore required students to resolve an ill-defined problem with a myriad of potential solutions, and as the evaluation showed, they relished the freedom to come to their own solution.

Finally, a large part of the course was geared to producing the kind of socially constructed understanding that makes for maximum transferability. Having discussed their ill-defined problem and possible solutions with each other and tutors, applied the conceptual models on offer, and built and tested a prototype in a team, the students experienced much negotiation over meaning and significance. They learnt what sources of information they could trust and how to use them, and the fact that virtual models don't exactly match reality no matter how good your numbers are. In short, they had begun to work as practitioners.

\section{Conclusion}

The challenges of engineering "cornerstone" design courses can be met by the deliberate design of both course delivery and assessment based upon knowledge of practitioners ${ }^{11}$ processes and systems. Concepts and fundamentals must be constructively aligned to downstream artefacts of multiple hands-on design projects to allow students to develop engineering skills and competencies. The FC, where material is delivered online allowing face-to-face interactions to be grounded in authentic disciplinary practices allows students to demonstrate practitioner competencies by involving them actively in their learning. For many students this is a new and unfamiliar demand and we believe this accounts for many of the "undecided" responses in the survey, especially for the question about how well structured the students perceived the course to be (Figure 7).

\begin{tabular}{|c|c|c|c|c|c|c|c|}
\hline \multirow{3}{*}{$\begin{array}{l}\text { The course } \\
\text { was well } \\
\text { structured }\end{array}$} & $\begin{array}{c}\text { Strongly } \\
\text { Agree }\end{array}$ & Agree & Neutral & Disagree & $\begin{array}{l}\text { Strongly } \\
\text { Disagree }\end{array}$ & $\begin{array}{c}\text { Rating } \\
\text { Average }\end{array}$ & $\begin{array}{l}\text { Rating } \\
\text { Count }\end{array}$ \\
\hline & $7.9 \%$ & $24.5 \%$ & $29.1 \%$ & $24.2 \%$ & $14.4 \%$ & \multirow{2}{*}{$2.87 / 5$} & \multirow{2}{*}{368} \\
\hline & 29 & 90 & 107 & 89 & 53 & & \\
\hline
\end{tabular}

Figure 7: Student perceptions of course structure. 
When students have experienced mainly traditional forms of teacher-led learning environments which focus on well-defined problems with immutable meanings, we should expect that the switch to one where they are expected to drive their own learning in collaboration with peers and staff, distrust models until tried against reality and to decide for themselves when they have reached an outcome, will always create a certain level of cognitive and affective dissonance. The fact that such a radical shift in pedagogy has won as much approval as it has from students combined with the extensive and thoughtful nature of their comments on what they would like to see done better, encourage us to pursue the possibilities of the flipped classroom further. While there is much work to be done, the challenge of providing meaningful theory-practice learning experiences with massive class sizes appears to be achievable using the FC approach. It allows for scale-up, yet also ensures students actually achieve requisite theoretical knowledge, professional ability, and behavioural learning outcomes.

\section{References}

1. Brown, A. (2012). A Phenomonological Study of Instructors Using the Inverted or Flipped Classroom Model. PhD Dissertation, Pepperdine University, October 2012.

2. Dori, Y., \& Belcher, J. (2005). How Does Technology-Enabled Active Learning Affect Undergraduate Students' Understanding of Electromagnetism Concepts? The Journal of the Learning Sciences, 14 (2): 243-279.

3. Dym, C., Agogino,A., Eris, O., Frey, D., \& Leifer, L. (2005). Engineering Design Thinking, Teaching and Learning. Journal of Engineering Education 94 (1): 103-120.

4. Entwistle, N., Peterson, R., (2004). Conceptions of learning and knowledge in higher education: Relationships with study behavior and influences of learning environments. International Journal of Educational Research, 41 (2004) pp. 407-428.

5. Froyd, J., \& Ohland, M. (2005). Integrated Engineering Curricula. Journal of Engineering Education 94 (1): 147-164.

6. Jolly, L. (2014). Curriculum Renewal in Engineering Through Theory-Driven Evaluation. A report to the Commonwealth Office of learning and Teaching, Canberra.

7. Little, P., \& King, J. (2001). Selection criteria for Cornerstone and Capstone Design Projects. International Journal of Engineering Education 17 (4 \&5): 406-409.

8. McLaughlin, J., Roth, M., Glatt, D., Gharkholonarehe, N., Davidson, C., Griffin, L., Esserman, D., \& Mumper, R. (2014). The Flipped Classroom: A Course Redesign to Foster Learning and Engagement in a Health Professions School. Academic Medicine 89 (2): epub ahead of print available at http://www.ncbi.nlm.nih.gov/pubmed/24270916.

9. Prince, M. (2004). Does Active Learning Work?: A review of the literature. Journal of Engineering Education 93 (3): 223-231.

10. Reidsema, C., Kavanagh, L., Jolly, L. (in preparation). Processes of student learning in the Flipped Classroom.

11. Seely Brown, J., Collins, A., \& Duguid, P. (1989). Situated Cognition and the Culture of Learning Educational Researcher, 18 (1):32-42.

12. Sullivan, L.E. (2009) Situated Cognition. In The Sage Glossary of the Social and Behavioural Sciences. DOI:http://dx.doi.org.ezproxy.library.uq.edu.au/10.4135/9781412972024 